
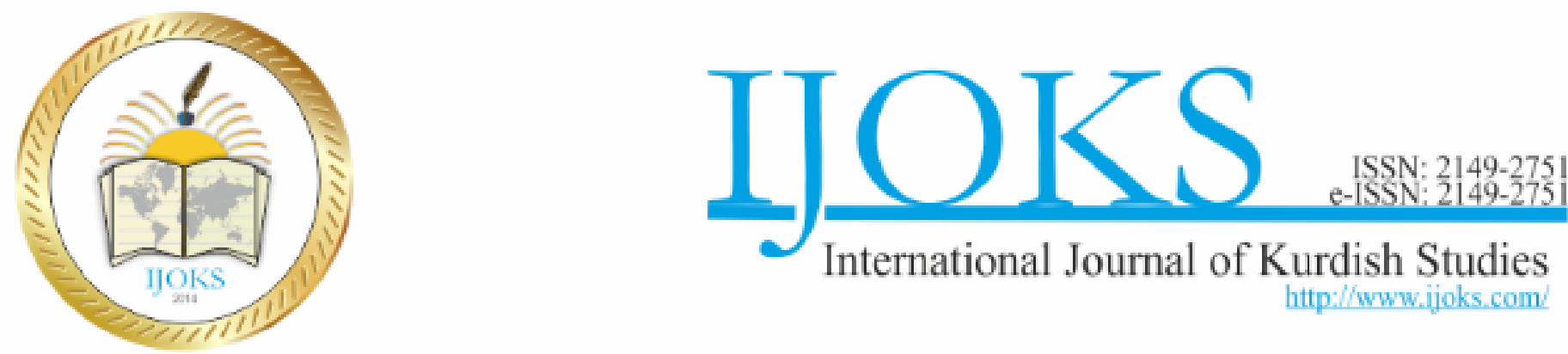

International Journal of Kurdish Studies

http://www.jijoks.com

\title{
Article
}

\author{
International Journal of Kurdish Studies \\ $6(1)$, pp. $52-69$ \\ http://ijoks.com
}

\section{Salīm Barakāt as Arbiter between Good and Evil: According to His Long Poem al- Mu'jam (The Obscure)}

\author{
Aviva Butt ${ }^{1}$
}

Received: Nov 01, 2019

Reviewed: Dec 10, 2019

Accepted: Dec 16, 2019

\begin{abstract}
Salīm Barakāt, Syrian Kurdish poet, completed his thirty-page poem al-Mu'jam (The Obscure) in 2004. The poem deals with the relationship between the poet and Evil, the relationship of Evil to Good, and the failure of Good to persuade in the face of Evil's deceptive ways. We see the poet as a failed arbiter between Evil and Good. Reason and rationality do not prevail. Consequently, there is a need for an intercessor on the Day of Judgment. The poet is convinced that remorse will win an acceptable intercessor, the Mercy of Allah. The poem throughout is a journey through the Qur'ān from beginning to end. It is also the poet's journey towards the Sufi goal.
\end{abstract}

Keywords: Salim Barakat, al-Mu'jam, The Obscure, Sufi, Kurdish poet

\section{Recommended citation:}

Butt, A. (2020). Salīm Barakāt as Arbiter between Good and Evil: According to His Long Poem al$\mathrm{Mu}$ 'jam (The Obscure). International Journal of Kurdish Studies 6 (1), 52 - 69

DOI: https://doi.org/10.21600/ijoks. 641719

\section{Enlighten them,}

O Evil,

About yourself as originator

So that they can assess the reality of the size of the stone

- Salìm Barakāt

\footnotetext{
${ }^{1}$ Corresponding Author, Independent scholar, Tasmania, Australia: avivabutt@winshop.com.au
} 
Barakāt introduces the subject of reason and rationality into his discourse on Good and Evil, almost immediately:

Good is penetration as to the deceptiveness of remorse. Good shall surely revert To the rational for his investigation of the mind's stirrings, be resigned to his pitying Evil's fate as a result of his remorse - the remorse of the dying. Call to him, O Evil; Call Good away from an end that is without prior succession; without future succession (11.10-13).

In keeping with the principle that the inner meaning of the Qur'ān is based on reason, Barakāt lets us know here and elsewhere that meaning starts from reason. The online forum ShiaChat tells us that

The Ismā' $\bar{l}$ li tâ'wīl is based on reason. The word $t \bar{a}^{\prime} w \bar{l} l$ in Arabic means to go to the first, primary or basic meaning of the word. According to the is, each and every verse of the Qur'ān has a basic meaning or hidden meaning apart from the manifest or secondary meaning. ... [the Mu'min] believes in the hidden or original meaning (bạtin) of the Qur'anic verses. The is maintain that there is difference between a Muslim and a Mu'min. One who recites the kalima and performs all the manifest rituals (zāhirī) like offering prayers, fasting, giving zakāt, performing hajj etc. is a Muslim. But a Mu'min is more than being a Muslim. A Mu'min is one who not only performs the zāhirī rituals but also believes in bạtin, the real, the original, the intended, meaning of these rituals. ${ }^{2}$

Barakāt's poem is complex. It is multilayered and multivalent, in itself a literary rendition of

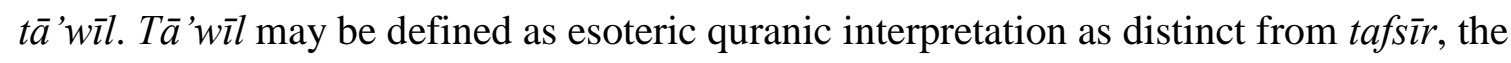
commentary that usually accompanies English translations of the Qur'ān. Relevant to the poem and the poet under discussion, is that mainly i and Sufi scholars recognize the $t \bar{a}$ 'wĭl as an 'inner' quranic hermeneutic. In keeping with the theorizing of the Syrian Alawite poet Adūnīs (b. 1930), Barakāt sees Arabic poetry as using the language of pre-Islamic poetry, continuing the Sufi trend of Islamic medieval poets, and leaning on quranic literary discourse to open up unlimited horizons in poetry. ${ }^{3}$ He writes mainstream poetry insofar as he is aware of the theorizing and creativity of other modern poets. Moreover, he does not hesitate to avail himself of especially surrealism, and other Western techniques that may have penetrated modern Arabic secular literature.

\footnotetext{
${ }^{2}$ https://www.shiachat.com/forum/topic/235010386-quran-interpretation-according-to-ismaili-tā’ wīl/

${ }^{3}$ See Adonis [English artistic name of Adūnīs], An Introduction to Arabic Poetics. Chapter 2: Poetics and the Influence of the Quran), p. 42. Barakāt has not written a poetic manifesto, or other theoretical treatise.
} 
The present writer sees the essential frame of Barakāt's complex poem as being the Qur'ān itself. He writes a philosophical poem that makes use of the methodology of ancient Greek literary philosophy, not as the Greek philosophy embedded in the thought of Western philosophers; on the contrary, as evolving from the same Greek rationality that entered Islam and Judaism as religious philosophy. The poet invokes the divine sphere of action by calling the senses into play as the senses are the touchstone of rationality. Like other mainstream poets, Barakāt sees this method as opening the way to convince. In his poem The Obscure, Barakāt uses sound suggestiveness, known as sound symbolism, and a symbol that jolts, the sound of the snake:

Constant vilification of true religion disconnects you from the throat of Good, And Good revels in your atonement, sempiternity's snakes that you wallow in, O Evil (11. 44, 45).

In the above lines, the Arabic word ghufrānaka (your atonement) has a sound similar to the Arabic word for "snake"/ al-af"awān connecting the two words and substantiating the actuality of an atonement that will lead to repentance. ${ }^{4}$

Another instance of sound symbolism, also evoking the snake, is to be found in the below lines:

How did you fashion all this? How did you fashion the ill-fated tree, tigers rub Their haunches on its scratchy bark; the tree is good for its ill-fated fruits? (1l. 55, 56).

The Arabic word for "ill-fated" / al-nahas sounds the same as the Hebrew word for "snake," with a slight change due to the interchangeability of sounds from language to language - the "s" sound becomes "sh" in the Hebrew.

In my recent article The Unimaginative Symbols of Salìm Barakāt (2018), we see that Barakāt in his philosophical poem of 1986, Hazā in Manhūba (dubbed "Glimpses of Spoliation," but literally “Stolen Treasures”) follows Shah Ismā‘̄il I, sixteenth century founder of the Safavid Dynasty in Iran. ${ }^{6}$ Shah Ismā ${ }^{`} \overline{1}$ by writing in a Turkic dialect provided the starting point for a linguistically more versatile modern Islamic literature, as differentiated from specifically Persian or perhaps Arabic literature. Shah Ismā'îl, whose father was the Kurdish Sufi, Sheikh Safī - writes in the qasī d form that traditional Arabic prosody uses.

\footnotetext{
4 اغفر انك / الأفوان / sour atonement cf. الإن / serpents.

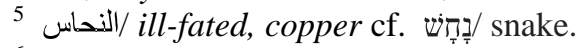

${ }^{6}$ A. Butt (2018), p. 298.
} 
Barakāt who actually writes in Arabic, and as a modern poet writes literature, takes Shah Ismā'īl's poems as a starting point for his modern poetry (al-shi'r al-hadīth) which uses the modernistic Arabic qașìdat al-nathr (the Arabic prose poem). At the same time, Barakāt has no objection to carrying over features or devices of the earlier modern trend in Arabic prosody, al-shi'r al-hurr (Arabic free verse) into his prose poems, an example being - 11. 517 / 518: . . But they neglected the bath *over you* the faint exhalation / Of the gods, and the faint inhalation of the gods. . . Here with the words "over you," we have the poetic device of in effect repetition of the words "over you," "over you" becoming a sort of pivot. One might say that Barakāt uses the device of the run-on line (enjambment) in the middle of the line of his prose poem. Enjambment, historically, characterizes al-shi ' $r$ al-hurr, together with irregular line lengths, the free use of rhymes (instead of the monorhyme of the qasīida), which is irrelevant to Barakāt, as well as the free use of classical metrics. Barakāt in the main uses the prose rhythms of qasīidat al-nathr, his line determined by the sense of his content. ${ }^{7}$ Further confirming Barakāt's hearkening back to Shah Ismā‘īl's poetry, is the underlying or overt subject matter of the Day of Judgment, a scarlet thread throughout Barakāt's poetry.

As said, the poem The Obscure is complex - multilayered, multivalent. The Qur'ān provides the frame for the poem, the poet roughly following the sequence of quranic $\bar{a} y \bar{a} t$ delineating the subject of Good and Evil, and providing the poet with a paradigm for insurgence throughout the ages. The poem seems to be contemporary literary $t \bar{a}$ 'w $w \bar{l}$ with the poet taking his symbols from the Qur'ān and the Islamic heritage. The background to Barakāt's narrative is in accord with the "tenet of early Ismaili $t \bar{a}$ 'wìl. . . that the written Qur'ān was but a reflection of the 'Qur'ān of Creation,' which itself contained the source of all symbols of the sacred. The Qur'ān supports this interpretation by mentioning the 'Mother of the Book' (umm al-kitāb, Sūra 43:4) and the 'Well-preserved Tablet' (lauh mahfüz, Sūra 85:22), which remain with Allah in pre-existence." "It seems that the narrative of Barakāt's poem with regard to his recurring theme of insurgence and its consequence relies heavily on the unadorned Story of Iblis as told in Sūrat al-A'rāf 7:11-25 - the story of the disobedience, punishment and reprieve of Iblis. ${ }^{9}$

\footnotetext{
${ }^{7}$ The line being determined by the sense of what the poet has to say affords the translator a certain amount of freedom in determining how the translated line will end!

${ }^{8}$ Neil Douglas-Klotz (2002). Re-hearing Quran in Open Translation (online article), p. 3.

${ }^{9}$ Other suwar that seem especially relevant to Barakat's narrative are: Sūrat al-Hijr 15:36-42, in which the Story of Iblis is placed in context of admonitions to heed Allah's signs; Sūra YāSīn 36:42-43; Sūrat al-Shu'arā’ 26:4243; Sūrat al-An'ām 6:116; and, Sūrat al-Isrā'17:36.
} 
The opening words of Barakāt's poem are to say the least high drama. There are from the start intertextual connections with the Qur'ān and in particular the quranic story of Iblis: Light's talons and the predators swoop down shivering from the shocks of the boon. / But do not fear. You are safe in my bed. . . S Sūrat al-A'rāf 7:11-25 tells the story of how Iblis fell and now inhabits the world. Iblis is not opposed to Allah, he is arrogant, disobedient and uncomprehending. Iblis' punishment is tragic, despite the promise of eventual reprieve - and here we have roughly speaking the paradigm for Barakāt's narrative. ${ }^{10}$ The below translation of three $\bar{a} y \bar{a} t$ from Sūrat al-A'rāf is according to my own understanding: ${ }^{11}$

11: We indeed created you and gave you human form. Then We told the angels to bow down to mankind. And they bowed down except for Iblis . . who was not of those who bowed down. 12: He said: What prevented you from bowing down as I told you. [Iblis] said: I am better than they are. You created me from fire . . but you created them from clay. . 13: He said: Descend from this [place] since it is not for you to be arrogant in it. Leave ${ }^{12}$

Lingering in the background throughout the poem are the words of Sūra 26, alShu'ara: 125-126:

\section{Indeed I am your trustworthy Messenger [A.B.]}

126a. So do not be cut off from Allah thus revolting [A.B.]

Or: $\quad 126 b$. So cleave to Allah and be submissive [A.B.]

Or: $\quad$ 126c. So fear Allāh, keep your duty to Him, and obey me. (The Noble Qur'ān, p. 498)

Or: $\quad$ 126d. "So fear Allah and obey me. (King Fahd Holy Qur-ān Printing Complex)

In regard to my translation $126 \mathrm{a}$ and $126 \mathrm{~b}$ above, I have presented alternate translations that I consider possible in view of the fact that the Qur'ān uses words with binarity, that is a verb and a participle that are both adḍ̄ad, to use a term in Arabic linguistics. Didd (plural: ad $\underline{a} \bar{d}$ )

\footnotetext{
${ }^{10} \mathrm{Or}$, as some Sufis would have it "Iblis refused to bow to Adam because he was fully devoted to God alone and refused to bow to anyone else. By weakening the evil in the satanic figure, dualism is also degraded, which corresponds with the Sufi cosmology of unity of existence that rejects dualistic tendencies." Online: https://en.wikipedia.org/wiki/Iblis [Accessed 21 March 2019].

${ }^{11}$ Unfortunately, English translations of the quranic text are not only as-is-known inevitably inadequate, but at times display a poor knowledge of Arabic linguistic features, and at times omit words or add words or wrongly introduce punctuation (perhaps the shabby work of editors?) for whatever reason - for which reason, and in relation to the work on hand, I feel free to submit my own translation - A.B.

${ }^{12}$ See https://www.youtube.com/watch?v=b0Hbr0xuu0I The quranic reader delivers the tragedy and pathos of the story of Iblis in his recitation.
} 
is the term for a word with two basic meanings, one the opposite or contrary to the other. The Arabic verb in question is 'attaqū'. ${ }^{13}$

The two respected English translations quoted above (126c and 126d) use the word "fear" without differentiating from other words in the Qur'ān that they also translate as "fear." Moreover, although their Arabic texts for this $\bar{a} y \bar{a} h$ are in accord, their texts do not agree with the text of the Qur'ān I purchased in Diyarbakir in the Old City in the Old Mosque square which I have taken to be the better text.

As regards line two of Barakāt's poem: But do not fear. ${ }^{14}$ You are safe in my bed - the words "do not fear" introduced from the outset will be repeated throughout the poem. As for the words "you are safe in my bed," to comment on the poet's poetic techniques that reveal meaning and at the same time address the masses, here and elsewhere he uses an ordinary word in an everyday register to call to mind the quranic text. In this instance, the ordinary word for a person's bed (sarīr) ${ }^{15}$ calls to mind Sūra 20:53, "who has made the earth for you as a bed," the fifth word of the quranic verse, bed (mahdan); ${ }^{16}$ and also Süra 43:10, the fifth word, bed (mahdan) ${ }^{17}$ again in context of "who has made the earth for you as a bed." The continuation of 43:10, "and has made for you passageways so that you will be guided," brings us to other lines in Barakāt's poem (Allah's / passageways, 11. 191, 192; Shoes from angels' ash are hurled from the passageways into the icy maze, $1.554^{18}$; For napping in the midday heat of the tinting lest they corrode the sky's passageways, $1.753 .{ }^{19}$

The above shows that Barakāt is adept at finding precise words for what he has to say. Moreover, he is adept at alluding to the Arabic quranic text in his own Arabic text. However, he nonetheless writes a poem that is conceived within the system of Kurdish language structures. If we consider that from vision / image to speech in any case involves an intervening transformation involving the speaker's imagination - it becomes obvious that choice of language is not of the essence.

\footnotetext{
${ }^{13}$ The Diyarbakir quranic text reads: فائَُّوا I I arrive at the meaning by comparing the Arabic to the Hebrew root letters: נתק.

فلا تَذفْ. : 14 Barakāt writes

آمينٌ أنتَ في سريزيَ. 15 / You are safe in my bed.

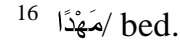

17 / مَهُْدًا 18 bed.

${ }^{18}$ Passageways / النو افذ إن basically meaning "exits."

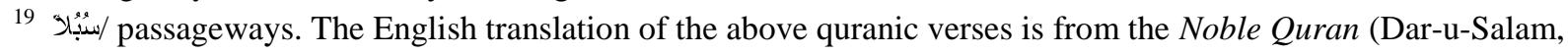
2007), Revised Edition: July, 2011.
} 


\section{Salīm Barakāt is a Kurdish Poet}

What kind of language is Kurdish? Referring to the erudite Kurdish Academy overview in the article the History of Kurdish Language, I surmise that as an ancient language, of course born without a formalized grammar, due to the wanderings of the Kurdish nation and the rise and fall of ancient civilizations and systems of belief, Kurdish was written down but in various scripts. These scripts brought with them changes in linguistic concepts, differing from region to region, and introduced "grammar." The Kurdish dialects do not discard old meanings of ancient vocabulary, but retaining these etymological meanings add new updated concepts into their language and into their vocabulary, as additional meanings for the same vocabulary. Or, new vocabulary is introduced. Arabic words are often accepted as being intrinsically Kurdish. Again, as an ancient language, Kurdish did not have a systematized verbal system of three-letter root/stem letters with vocabulary deriving from that system as do the Arabic, the Hebrew, and Aramaic with which we are familiar. Kurdish root letters may consist of one root letter, of course uttered as consonant plus indeterminate vowel sound; or two root letters; or three root letters; or reduplicated letters, as with Semitic languages. The Kurdish Academy insists on a strong resemblance to the Avestan language, but does not give details. Others have insisted that Kurdish is a Persian language. Again is that because of similarities in vocabulary, or more likely due to cultural similarities? In any case, Kurdish appears to have retained the vocabulary of the Kurdish original language which sometimes coincides with the Arabic, as Barakāt makes apparent in his poems when he affords us with an underlying alternate reading. In addition, Kurdish dialects by and large use the grammar of the above mentioned Semitic languages. Hence, one might draw the conclusion that Arabic is a likely if not preferable linguistic vehicle for a Kurdish poet living in an Islamic world.

Salīm Barakāt is a Kurdish poet who writes Arabic - he himself insists on saying this. The writer of the article 6.1 Salīm Barakāt and the Rise of a Kurdish Literary Discourse goes on to say that Barakāt writes as if Syrian society does not exist; that is, appropriating Arabic, he nevertheless writes within the space he creates for Kurdish culture. Syria at large, the same writer says, does not marginalize his writings, since it does not perceive the existence of the Kurdish nation in its midst. ${ }^{20}$ All this aside, Barakāt avails himself of poetic techniques that

\footnotetext{
${ }^{20}$ Tradition, Modernity, and Postmodernity in Arabic Literature: Essays in Honor of Professor Issa J. Boullata. Edited by Kamal Abdel-Malek and Wael B. Hallaq (2000), 6.1 Salim Barakat and the Rise of a Kurdish Literary Discourse, pp. 349-350.
} 
facilitate his own search-for-meaning, as for example his deliberate and frequent displaying of different meanings of words having the same root/stem letters. This technique, difficult as it is, is perhaps substantiated by the poem being in a genre that fits the mainstream description of "philosophical poem." Above all, his technique is symptomatic of Barakāt's overall search for origins. Reminiscent of what I see as a manifestation of the antiquity of language is when in the case of Kurdish, its extant dialects exhibit an abundance of similar sound structures with diverse meanings, rather than one basic meaning. Barakāt makes use of the binarity common to both the Arabic language and Kurdish dialects, and also used in the Qur'ān.

In the case of the poet-theoretician Adūnīs, I find only one instance of his using binarity as a poetic technique, and that is with the Arabic word $\left(f a d \bar{a}^{\prime}\right) .{ }^{21}$ He uses this word in both the first and second poems of his series of poems that comprise his long poem Fihris LiA 'māl al-Rīh (Index to the Acts of the Wind), 1998, as follows: ${ }^{22}$

This says:

The body writes

Only the body!

And he said:

With words - a space ${ }^{23}$

That does not sustain the body's splendor.

In the above lines from the opening poem The Body, space is used to indicate space as part of "presence." That is, without presence there is no "space." In the next poem, Day's Head on Night's Shoulder (verse 9, last line), the meaning of ( $\left.f a d \bar{a}^{\prime}\right)$ will be redefined as absence, as follows:

The trees in our village - female poets

Dipping their quills

Into inkwells of absence. ${ }^{24}$

Unlike Barakāt, and as is his wont, Adūnīs explains his technique: “"Mysticism' here does not mean detaching oneself from the real world, but only detaching oneself from its

\footnotetext{
${ }^{21}$ The Hans Wehr Arabic-English dictionary defines fa ${ }^{2} \bar{a}{ }^{\prime}$ as cosmic space!

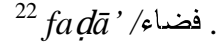

${ }^{23}$ Space: فضاء (fad $\left.{ }^{2}\right)$ - space as part of "presence."

${ }^{24}$ In this line, Adūnīs redefines the Arabic word فضاء $(f a d a \bar{a}$ '), which in the first poem A Body was "space" space as paired with "presence" - as فضاء "absence" as versus "presence."
} 
overt appearance, in order to attain its depths and plunge into its inner dimension, that which goes beyond the apparent to the concealed and from the 'present' to the 'absent.",25

Barakāt uses the technique of redefining words, which may appear as an instance of binarity or more likely as a shift in meaning, shifts in meaning being common throughout his long poem. We have an example of the former with the lines

Come, O Evil, we shall instruct twilight as regards the intrigues of purity and infidelity. Come we shall produce sunrise, again, as if asparagus, by visiting that same frivolous ash. And may we hurl it, together, towards the insensitive ice uninspired by feelings

For the abandoned. Come we shall trundle sunrise to them to the outrage of the trees (11. 420-423)

In the above lines, "sunrise" and "twilight" in Arabic are both fajr. The poet takes advantage of the ambiguity to accomplish the trundling or rolling around of a hefty load, the last twilight, for creating another sunrise. My interpretation is that as there is an ambiguity involved, the poet cannot ask Good for assistance. Instead, he asks Evil for help.

In the below lines, the Barakāt uses a shift in meaning to underline the change of location from the world of sempiternity to the transcendental world of a more remote antiquity: the word previously used for desert becomes labyrinth (al-tīh); ${ }^{26}$ and a word previously used for sempiternity becomes remote antiquity (al-qidam). ${ }^{27}$

He will throw completion's heavy net to the mammoth's cooper. ${ }^{28}$

There is no hunting

In the labyrinth

Of remote antiquity, $O$ Evil.

(11. 122-125)

The above poetic device is a meaning-making technique that provides stepping stones to origins, the origins of meaning, and accordingly instances of its use provide a passageway/exit to the no-meaning, the place. It becomes clear that Barakāt's multilayered and multivalent poem has an inherent purpose similar to his Sufi poem Mahmūd Darwīsh. ${ }^{29}$

\footnotetext{
${ }^{25}$ Adonis, Sufism and Surrealism, p. 172; see also pages 43 and 116.

التيه 26

الـقِدَم 27

${ }^{28}$ Mammoth: a huge extinct elephant.

${ }^{29}$ See Aviva Butt, Butt (2019). Salīm Barakāt's Intermediary Existence: His Poem Mahmūd Darwīsh. International Journal of Kurdish Studies 5 (1). Online: http://ijoks.com/ DOI: 10.21600/ ijoks.516511. See also Aviva Butt (May 2018). Sacred Texts and the Arabic Poetry of Mahmud Darwish. Archiv Orientální. Online: http://aror.orient.cas.czl.
} 
Earlier poets in modern Arabic literature, of the generation of the Iraqi poet 'Abd alWahhāb al-Bayātī (1926-1999), above Syrian poet 'Alī Aḥmad Sa'īd, artistic name: Adūnīs, and the Egyptian poet Șalāh 'Abd as-Sabūr (1931-1981) find "parallels between the stages of mystical experience and the poetic creative process, sometimes even stating that they are identical. ${ }^{30}$ In his article I saw my God in the eye of my heart: Mysticism, Poetry and the Creative Process in Modern Secular Arabic Literary Culture, Reuven Snir writes that

Arab poets also find parallels between the stages of mystical experience and the poetic creative process, sometimes even stating that they are identical. . . 'Abd asSabūr introduces new ideas and incorporates them into his own theory of the creative poetic process. Poetry is a kind of nashwa (ecstasy) and art in general is "the moments of ecstasy of human beings." "Abd as-Sabūr borrows the image of the Sufi progressing on the path toward the Divine essence: poetry is a path with many obstacles and risks, and he who chooses it takes his life into his own hands. ... ${ }^{31}$

As does Adūnīs, Barakāt merges mainstream techniques of surrealism with his Sufi poem. He makes use of techniques in surrealism in which the creative mind is released so that meaning will surface.

\section{Remorse, an Ongoing Theme}

Intertwined with the theme of insurgence, is the subject of remorse.

O Evil. Look here, the fortunes in gold,

What you desire preoccupies you: Good is convinced that volition has deserted;

Good's remorse is unstable due to its feverish cushions, disorientated, trembling, mute, Behind your covering the cry of al-Zair is detected, O Evil. ${ }^{32}$

How did you fashion all this? How did you fashion the ill-fated tree, tigers rub

Their haunches on its scratchy bark; the tree is good for its ill-fated fruits?

How did you fashion such intrepid good-good, remorse - a pair of udders a kind of

Prism of the known; good, remorse, offerings, the mortal world, succor coming along

With the knives of the certain; the redeeming good is in the confession that this last gasp Is due to its fuck? (11.52-60)

In keeping with surrealist notions of bringing "meaning" to the text by means of deautomatization of words and expressions, Barakāt's poem uses the word nadam for "remorse"

\footnotetext{
${ }^{30}$ R. Snir (2013). 'I saw my God in the eye of my heart': Mysticism, Poetry and the Creative Process in Modern Secular Arabic Literary Culture, p. 198.

${ }^{31}$ R. Snir (2013), p. 198.

${ }^{32}$ The cry of the Zair alludes to II Kings 8:21.
} 
- a less pompous word than for example the quranic tauba for "repentance." Moreover, Barakāt's choice of word again serves the poet's overall tendency to write in a register that personalizes and better brings across his message.

It is remorse that triggers Allah's compassion, and as the Kurdish Sufi Sa'‘̄d Nurs̄̄ (1877-1960, b. Eastern Turkey) confirms in his commentary on the opening word of the Qur'ān, Bismillahirrahmanirrahim, Divine Mercy is an acceptable intercessor: “Oh unhappy man struggling within a boundless impotence and endless want! You should understand just what a valuable means and acceptable intercessor is Divine Mercy. ..." 33

Remorse triggers Allah's compassion so that Allah as Compassion will act as intercessor. So, the poet tries to bring Evil to a state of remorse:

Injured, frozen, O Evil.

Injured, aimless - look here, you:

You vacillated at the sound of the ephemeral as to self-restraint in view of Good's loathing; As to gratification, the expropriation by you, by the blast's greed - by your lust, Whisperers are greed's singers, beggary's whistle, in fact beggary along Allah's Passageways, sweeps away the spoils of the ignorant and the fickleness of scholars. You vacillated at a whisper of error and sensing of uproar:

An error of imbalance

(11. 187-195)

\section{The Poem Itself}

In his poem, The Obscure, the poet personalizes by depicting himself as feeling a certain affection and admiration for Evil! At the start of the poem, he welcomes Evil, saying: But do not fear. You are safe in my bed. And, no wonder, if we stop and think - there is no universe and no creativity without the dichotomy of Good and Evil! Moreover, the poet is comfortable in an ongoing personal dialogue with Evil - he wishes the Kurdish nation would understand the fallacies in Evil's persuasive arguments:

$M$

$A$

$R$

${ }^{33}$ Bediüzzaman Said Nursi. Risale i-Nur [Turkish]. Online English translation: http://h4h.org/ Select Risale-i Nur: The Sixth Mystery. Sa 'īd Nursī writes modern Kurdish Sufi commentary on the Qur’ān. Turkish Kurds call him "al-Kurdi." 
Cracks in the rock borne on your shoulders, O Evil. And the brutish in spirit shall go out To pasture in strides, herded from amassed inheritance, the more lazy in the stalls, Peaceful as proof that their stunned monkey's hearts are baffled by the sacred sand dunes, Where there is nothing, as yet, except a devastated arbiter as proof.

(11. 399-409)

Yes, the poet acts as arbiter, a sort of Islamic judge . . . between Good and Evil . . . but, apparently without any real success. In his ongoing dialogue with Evil, the poet sometimes pleads with Evil. In the following lines, the poet tries once more to reason with Evil:

Tamed like the insurgent, Good details his confession on your behalf, O Evil, Since you do not preoccupy him, ${ }^{34}$ his gratitude for al-Qiyamah is in Good's province. In you, and only you, al-Qiyamah escapes his issue - Good's issue, it bites into The muscle of the tale itself; the fabricated tale, concise and prosaic, midst the chattering of Sempiternity's sisters, $O$ Evil.

(11. 60-64)

In general, in the above lines, and elsewhere, and in previous poems, the poet gives an impassioned account of events that have their repeat throughout Kurdish history, especially the tragedies surrounding Kurdish insurgents, fighters who will be martyred, and as a sort of counterpoint, an account of the sacrifices of the dedicated in the face of the situation of greed for wealth, especially on the international scene. Adding suspense is always the Day of Judgment or al-Qiyamah in the background, sometimes stepping into the foreground to provide a narrative account of its own. These narratives not only add suspense, but also a sense of relevance to the poet's message.

With this poem, we see the mature poet, the perennial poem-of-the-poet's-being expressed loudly and clearly. But, I for one would have no chance of understanding it without having been familiar with Barakāt's earlier writings.

\footnotetext{
${ }^{34}$ Here, "him" refers to the insurgent who will be "martyred."
} 
The "grand finale" of Barakāt's thirty page poem The Obscure is in actuality three short poems all with the same title repeated - "Do not fear" (Lā takhawf) ${ }^{35}$ The words "do not fear" have been heard previously, albeit less conspicuously, but nevertheless in retrospect contribute to the cumulative effect of the ending of the poem. On one hand, Barakāt's grand ending is a direct expression of Kurdish Sufism, that is, the three short poems are modern Sufi poems, in which the poet again asserts that Divine Mercy is an acceptable intercessor. On the other hand, Barakāt lapses into modern Western techniques of vers libre (free verse) with the technique of especially the third of the three modern short poems, written in a semblance of Arabic free verse (al-shi'r al-ḥurr).

The three short poems are, as follows:

\section{Do not fear}

Indeed pain will restore death to legend. The womb's pain; the bones are coached to its Refrain; the refrain of dawn; the dreamer of the entire irreality is in that very chamber-

The chamber of universal knowledge; cosmic equilibrium; the accurate in orphaned news For the fortunate; the scion from their wage; the Nürsing father with the huge breasts; Summons realities from the veiled.

\section{Do not fear}

Did not the dead restore inscription after inscription?

Restore death, $O$ Evil. Assure them of the uncommon, of speaking the language of orchards His language - the seeds of immortal misguidance. Apportion to him what is suitable For the suave urbane: brick furnaces, and baskets for new covenants such as "dandelions. "36

\section{Do not fear}

Hunters! Water is in the hands of the hours of the sand:

The water, the hour.

The sand, the hour.

The ray, the hour, deflected when mirrored on geese feathers.

Coincidence, the hour.

Flies, the hour.

The yellowish dragonfly, the hour, in flight, with seven wings wrapped round

The hour, the water.

Hunters! Water hovers around them.

The belated hour for their entrance into the no-time $;^{37}$

\footnotetext{
${ }^{35} \underline{\text { Khawf }}$ as fear is generally understood to imply a basic, physical fear, such as fear of hunger.

${ }^{36}$ Dandelions, that is, "remedies."
} 
The rebellious hour, the hour of Good's entrance into you Resigned to showing you the missing inscription.

I see it,

The inscription, Karac

The missing, O Evil:

A sacrifice to naught for naught.

A sacrifice of words so that thus you will shelter them from Allah, And you will dispose of them struck down in their blood.

In the above lines, the poet uses the poetic device of repetition made famous in modern English poetry by the American poet Amy Lowell (1874-1925). Her poems were described as being vers libre (free verse); she herself said that she wrote "cadenced verse" and claimed that "cadence is rhythm." Her poetry and concept of cadenced verse and the importance of the rhythmical underlying structure in modern unrhymed verse took hold among modern Arabic poets. Arabic poets such as “al-Bayyātī, al-Sayyāb, Fu'ād Rifqa, Adūn̄̄s (English name: Adonis), 'Abd al-Sabūr, and Hijāz̄̄”" used reiteration to produce "an elliptical repetition which adds depth to the poem and carries the theme to its climax" - "this method of ending a poem was condemned by Nāzik al-Malā’ika ...” [see Moreh (1976), pp. 229-230]. However, on examining the concluding section of Barakāt's long poem The Obscure, we see evidence that the poet grafts Western techniques onto his modern Sufi poem - contrary to al- Malā'ika's hasty opinion - most successfully! The repetition of associated words that might otherwise appear to be the poetic device of reiteration, with Barakāt takes on the aura of Sufi spontaneity; especially read aloud, the poem's rhythm recalls the Sufi whirling and twirling that induces an upsurge of awareness from the universal meditative mind.

\section{Conclusion}

Throughout the poem, we are presented with a narrative on the theme of Good and Evil - the underlying theme of the whole of the Qur'ān. Throughout his poem, the poet introduces various motifs in relation to Good and Evil, and in addition gives an impassioned account of historical events, events that have their repeat throughout Kurdish history. That Barakāt writes in Arabic as the language of his choice does not detract from the "Kurdishness" of his poem - all the more so, since the original Kurdish language is no longer extant, and we have only surviving dialects. I have indicated from time to time that the poemof-his-being, what Maurice Blanchot calls "the work," is a Kurdish poem, both at the

\footnotetext{
${ }^{37}$ No-time, the waqt: the theoretical vertical line that is the divide between the past and future, i.e. the theoretical present.
} 
linguistic level and the emotional level - an ongoing unarticulated poem that the poet transposes to Arabic and articulates in Arabic. In so doing, he not only summons the origins of the Kurdish language but also confirms Kurdish identity. He stretches the Arabic language to its limits, adding new vocabulary to express his Kurdish and Islamic themes; and, in addition, taking advantage of possibilities inherent in Arabic grammar, Barakāt innovates thus contributing to the musicality of modern Arabic poesy.

The present writer has tried to reveal some of the techniques Barakāt uses to achieve his poetic goals, in anticipation that such activity will facilitate a deeper understanding for both herself and in general Barakāt's readership. I have taken as a premise that Barakāt recognizes an inner hermeneutic of the Qur'ān known as "tâ'wīl " that is known primarily to him as an i and Sufi scholar. The surface narrative of the poem arising from this study could be summarized as follows: The poem deals with the relationship between the poet and Evil, the relationship of Evil to Good, and the failure of Good to persuade in the face of Evil's deceptive ways. We see the poet as a failed arbiter between Evil and Good. Reason and rationality do not prevail. Evil does not listen to the poet's plea. Consequently, there is a need for an intercessor on the Day of Judgment. The poet is convinced that remorse will win an acceptable intercessor, the Mercy of Allah: Let the witnesses come forth, at the blood-red completion ${ }^{38}$... . Peaceful as proof that their stunned monkey's hearts are baffled by the sacred sand dunes / Where there is nothing, as yet, except a devastated arbiter as proof.

In the above lines, the poet as "a devastated arbiter" steps into the foreground of his poem.

The poem throughout is a journey through the Qur'ān from beginning to end, accomplished mainly by intertextual connections. The poet takes us on a journey of return to the rational as touchstone to "the original spiritual and luminous reality of the Qur'ān [that] is called esoteric interpretation (tā'wīl) since the very word "tā'w̄̄ll" comes from the word awwal, meaning "first" or "origin." 39 It is also the poet's journey towards the Sufi goal, accomplished mainly by a constant revealing of meaning as a stepping stone to origins. Barakāt takes us with him on these combined journeys. On one hand he addresses the masses, and on the other hand he leads us as individuals to the ecstatic state.

\footnotetext{
${ }^{38}$ Completion, i.e. al-Qiyamah.

${ }^{39}$ Imam Shah Karim al-Husayni Aga Khan IV (28 December 2015, posted by Ismaili Gnostic). Esoteric Interpretations of the Qur'ān: The Foundations of Shia-Ismaili Tā'wīl, p. 6.
} 
Especially contributing to my own understanding of the creative process are Adūnīs' long poem Fihris $L i-A$ ' $m \bar{a} l$ al-Rịh telling the story of the creative process from beginning to end as well as the theories of the Egyptian poet 'Abd as-Sabūr who equates the creative process with the Sufi mystical path - 'Abd as-Sabūr's theories being known to me through the writings of Professor Reuven Snir.

Salīm Barakāt (b. 1951, Qamishli, Syria), a Syrian Kurdish poet, and the older Syrian poet and theoretician Adūnīs (b. 1930), whose background is Alawite (a Syrian Kurdosyncretic system of belief) are today's leading poets in Arabic literature. Strangely, until the International Journal of Kurdish Studies - Diyarbakir started to publish my articles with translations of Barakāt's poems in context of some explanation of the historical background and the poet's writing techniques, Barakāt's poetry had remained a "closed book" for the Western world.

\section{References}

Adonis (2003). An Introduction to Arab Poetics. (trans. Catherine Cobham) London: Saqi. First published as Adūnīs (1985), Introduction à la poétique arabe (Beirut: Dar alSaqi).

Adonis (2005). Sufism and Surrealism. (trans. Judith Cumberbach). London: Saqi.

First published as Adūn̄is (1995), al-Sufiyya wal Surriyaliyya (Beirut: Dar al-Saqi).

Adūnīs (1998). Fihris Li-A 'māl al-Rīh [Index to the Acts of the Wind]. Beirut: Dar al-Nihar lil-Nashr.

Avesta. http://www.avesta.org/

Barakāt, Salīm (2007), al-Amāl al-Shi 'riyyah Salīm Barakāt [The Poetry Works of Salīm Barakāt]. Beirut: al-Mu'assash lil-Dirasat wa-Nashr (The Foundation for Studies and Publishing).

Blanchot, Maurice (1955), trans. Ann Smock. (1982). The Space of Literature. University of Nebraska Press.

Butt, Aviva. (2019). Salīm Barakāt's Intermediary Existence: His Poem Mahmūd Darwīsh. International Journal of Kurdish Studies 5 (1), 328 - 358. http://ijoks.com/ DOI: $10.21600 /$ ijoks.516511

Butt, Aviva. (2018). The Unimaginative Symbols of Salīm Barakāt. International Journal of Kurdish Studies 4 (1), 44 - 69 (August 2018). http://ijoks.com/ DOI: 10.21600/ijoks.383376 
Butt, Aviva. (2018). Empire, Split Ethnicities, and an Explosion of Poetry. International Journal of Kurdish Studies, Volume 4 - Issue 1 - Jan 2018. http://ijoks.com/ DOI: 10.21600/ijoks.383376

Butt, Aviva (2018). Sacred Texts and the Arabic Poetry of Mahmud Darwish published by the Oriental Institute (CAS), Prague, Issue 86.1 - ISSN 0044-8699. ArOr (Archiv Orientální): http://aror.orient.cas.cz/ No free access for 2 years from date of publication (May 2018).

Chyet, Michael L. (1999). Em hînî Kurmancî dibin Online: https://www.scribd.com/document/302602640/ingilizikurdi [accessed 18 March 2019].

Douglas-Klotz, Neil (2002). Re-hearing Quran in Open Translation: Ta'wil, Postmodern Inquiry and a Hermeneutics of Indeterminacy. Online: http://abwoon.org [Accessed 24 July 2018].

Hans Wehr Dictionary of Modern Written Arabic: Arabic - English. Edited by J.Milton Cowan, Fourth Edition (1994), compact edition published by Spoken Language Services, Inc., Ithaca, New York.

Hintze, Almut (2000). Fraso.Kereti. In: Encyclopedia Iranica, vol. X, fasc.2, pp. 190-192. Online: http://www.iranicaonline.org/articles/frasokrti (updated 31 Jan 2012).

Imam Shah Karim al-Husayni Aga Khan IV (2015). Esoteric Interpretations of the Qur'ān: The Foundations of Shia-Ismaili Tā'wīl. (posted by Ismaili Gnostic). Online: https://ismailignosis.com/2015/12/28/esoteric-interpretations-of-the-quran-thefoundations-of-shia-ismaili-tā'wīl/ [Accessed 1 October 2018].

Islamic HelpLine: http://www.islamhelpline.net/node/1491 [Accessed 27 February, 2019]

Kamal, Abdel-Malek, and Hallaq,Wael B. edited by (2000). 6.1 Salīm Barakāt and the Rise of a Kurdish Literary Discourse (ISBN 9004 117636). Tradition, Modernity, and Postmodernity in Arabic Literature: Essays in Honor of Professor Issa J. Boullata, pp. 349-350. Leiden, The Netherlands, Koninklijke Brill NV.

Kappagoda, Astika Kautilya (July 2004). Semiosis as the Sixth Sense: Theorising the Unperceived in Ancient Greek (doctoral dissertation, 647 pp.). Sydney Australia: Department of Linguistics, Macquarie University. [Online] Available at: http://www.isfla.org/Systemics/Theses [Accessed 20 Jan 2018].

Karacan, H. (2020). Kurmanji and Zazaki Dialects: Comparative Study on their Phonetics. International Journal of Kurdish Studies 6 (1), 35 - 51 DOI: https://doi.org/10.21600/ijoks. 653812

Karacan, H , Khalid, H . (2016). Adjectives in Kurdish language: Comparison between dialects. International Journal of Kurdish Studies , 2 (2) , 0-0 . DOI: 10.21600/ijks.76230

Karami, Mahnaz and Kazerouni, Seyyed Ahmad Housseini Dr. (2016). The Psychology of Obedience and Insurgence in Quranic Verses (S. 26 al-Shu'ara: 125-126). In the form 
of a fixed Special Issue February 2016, International Journal of Humanities and Cultural Studies ISBN2356-5926. Online: http://www.ijhcs.com/index.php/ijhcs/index Page 2785 [Accessed 8 July 2018].

Kitāb Asās al-Tā'wīl (Foundation Tā'wīl ) (2018). Syria: Dār al-Ghadīr Sūrīya - Salamīya.

KurdishAcademy.org/2011/04/10/the-history-of-kurdish-language/ The History of the Kurdish Language,[Accessed 15 March, 2019].

McDowell, David. (2004). A Modern History of the Kurds Third Edition. London and New York: I.B. Tauris.

Minorsky, Vladimir and Shah Ismail I (1942). The Poetry of Shah Ismail I. In: Bulletin of the School of Oriental and African Studies. Cambridge: Cambridge University Press on behalf of School of Oriental and African Studies.

Moreh, S. (1976). Modern Arabic Poetry 1800-1970. Leiden: E.J. Brill.

Meyerhoff, Hans (1960). Time in Literature. Berkeley and Los Angelos.

Pfannkuchen, Antje and Weatherby, Leif (2017). Wrting Polarities: Romanticism and the Dynamic Unity of Poetry and Science. Online: https://doi.org /10.1080/00168890.2017.1370941 [Accessed 21 March 2019].

Qur'ān. Tanzīl min Rabi-l- 'Ālamīn. Diyarbakir Turkey: 2018.

al-Ramahi, Aseel. Sulh: A Crucial Part of Islamic Arbitration. December 2008. London School of Economics and Political Science. Online: http://www.lse.ac.uk/law/working-paper-series/2007-08/WPS2008-12-Al-Ramahi.pdf [Accessed 8 February 2019].

Sa'īd Nurs̄̄ , Bediuzzaman (aka al-Kurdi). Risale i-Nur. Online English translation: http://h4h.org/ . Risale-i Nür. [Accessed 23 February, 2019].

Skjaervo, Prods Oktor, introduced, translated, and edited by (2011). The Spirit of Zoroastrianism. New Haven and London: Yale University Press,.

Snir, Reuven (2003-2004). Modern Arabic Literature and Islamist Discourse: "Don't Be Coolness, Don't Flutter Safety." Journal of Arabic and Islamic Studies 5, edited by Lutz E. Edzard and Stephan Guth. Norway: University of Oslo, pp. 78 - 123. Online: http://www.lancaster.ac.uk/jais/volume/docs/vol5/5_Snir.pdf [Accessed 27 March 2018].

Snir, Reuven (2013). "I saw my God in the eye of my heart": Mysticism, Poetry and the Creative Process in Modern Secular Arabic Literary Culture. Branches of the Goodly Tree: Studies in Honor of George Kanazi, edited by Ali Ahmad Hussein (book). Wiesbaden, Germany: Harrasowitz Verlag, pp. $194-229$. 